\title{
Evaluation of soil fertility and yield regression in apple orchards of Western Himalayas
}

S.K. ATTAR AND N.K. JOOLKA

\author{
MEMBERS OF RESEARCH FORUM: \\ Corresponding author : \\ S.K. ATTAR, Agricultural \\ Experimental Station (N.A.U.), \\ Paria Farm, Ta. Killa Pardi, VALSAD \\ (GUJARAT) INDIA
}

Co-authors :

N.K. JOOLKA, Department of Pomology, Dr. Yashwant Singh Parmar University of Horticulture and Forestry, SOLAN (H.P.) INDIA
Received : 16.06.2015; Revised : 21.10.2015; Accepted : 07.11.2015

\section{Summary}

A nutritional survey was carried out to evaluate soil fertility status in major apple growing belts viz., Jubbal-Kotkhai, Karsog, Kalpa, Kotgarh and Naggar of Himachal Pradesh (India) situated in the core of Western Himalayas and also to study the effect of nutrient concentrations on influencing yield. Soil samples were collected from twenty five orchards for two years and concentrations of nitrogen, phosphorus, potassium, calcium, magnesium, iron, manganese, copper and zinc were determined. The soil macro-nutrients $\mathrm{N}, \mathrm{P}, \mathrm{K}, \mathrm{Ca}, \mathrm{Mg}$ in different locations were found in the range 95.11-202.58, 8.03-68.03, 53.11-278.07, 726.12-2727.11 and 126.28$446.10 \mathrm{ppm}$, respectively while, the micro-nutrients $\mathrm{Fe}, \mathrm{Zn}, \mathrm{Cu}$ and $\mathrm{Mg}$ varied from 31.27$78.23,0.64-4.23,1.18-4.80$ and $9.97-52.11 \mathrm{ppm}$. Multiple regressions have been calibrated for predicting apple yields at different locations and for low and high yielding (>150 kg/tree) trees, where the models were found to have a high and significant predictability value. Using the data, fertilizer adjustment equations can be developed for prescribing optimum fertilizer doses for attaining high yields in the apple production areas in the Western Himalayas and indeed elsewhere with similar climatic and soil conditions.

Key words : Fertilizer, Apple, Essential nutrients, Regression plane, Critical limits

How to cite this article : Attar, S.K. and Joolka, N.K. (2015). Evaluation of soil fertility and yield regression in apple orchards of Western Himalayas. Asian J. Soil Sci., 10(2) : 242-247. 